I 308

\title{
酸化プロピレンのラットを用いた吸入曝露による 生殖発生毒性
}

奥田 裕計 ${ }^{1}$ 、竹内 哲也 ${ }^{1}$ 、笠井 辰也 ${ }^{1}$ 、長野 嘉介 ${ }^{1}$ 、山本 静護 ${ }^{1}$ 、 松島 泰次郎 1

${ }^{1}$ 中災防 日本バイオアッセイ研究センター

\section{【はじめに】}

酸化プロピレンは、プロピレングリコールやその誘導体の製造、顔料、医薬品の中間体、殺菌剤として用 いられ、生産量は 334,665 トン(平成 14 年)である。酸化プロピレンを取り扱う作業環境における労働者への 主な曝露形態は吸入経路であることから、ラットを用いて吸入嚗露による生殖発生毒性を検討した。

【材料及び方法】

酸化プロピレン(和光純薬工業、純度 100\%)を設定濃度で、吸入チャンバーを用いてラットに全身暴露した。 吸入チャンバー内の濃度は、自動サンプリング装置付ガスクロマトグラフにより 15 分ごとに測定、監視した。

反復投与毒性・生殖発生毒性併合試験 (ReproTox 試験 : OECD 化学品テストガイドライン 422) : CD(SD)IGS ラットの雌雄、各群 10 匹に 1 日 6 時間、14 日間、125、250、500、1000 ppm の濃度で曝露後、同じ投与濃度 群内の雌雄を $1: 1$ で交配させた。交配期間中及び交配終了後も曝露を継続し、雄は計 42 日間の曝露、雌は妊 娠 19 日まで曝露させた後に自然分婏させ、児動物を生後 4 日まで哺育させた。一般状態の観察、体重测定、 血液学的検查、血液生化学的検查、病理検索に加えて、生殖発生䏝性を検討するために、精子検查、性ホルモ ン検查、性周期観察、交尾能、受胎能、分娩・哺育状態の観察、児動物の生死や体重測定等を実施した。

発生毒性試験 : 妊娠 CD(SD)IGS ラット、各群 5 匹に 1 日 6 時間、妊娠 6 日から 19 日まで 125、250、500、 $750 、 1000 \mathrm{ppm}$ の濃度で曝露した。妊娠 20 日に帝王切開により胎児を摘出し、胎児の生死、重量測定、外表・ 内臓・骨格の形態観察を行った。

\section{【結果及び考察】}

ReproTox 試験：1000 ppm では、懪露後期に死亡する動物がみられた。また、この濃度では後肢の歩行異 常も観察された。500 ppm 以上で体重増加抑制がみられ、鼻腔を含む気道及び肺に炎症が認められた。精巣 では $1000 \mathrm{ppm}$ で精母細胞の壊死が散見され、精巣上体尾部から得た精子を検查したところ、精子数の減少 や精子運動能の低下が認められた。さらに、1000 ppm では精囊と前立腺重量が低下し、血清中のテストステ ロン濃度が僅かに低下していた。雌には $1000 \mathrm{ppm}$ で性周期の不規則性が数例にみられた。雌雄への 14 日間 の曝露後の交配から得られた交尾率、受胎率、着床率には明らかな差はみられなかったが、 $1000 \mathrm{ppm}$ で児を 出産した母動物は 1 例もなく、全胚が子宮内で死ししていた。

発生毒性試験：750 ppm 以上の濃度で母動物の体重増加抑制があり、胎肾の重量が低下したが、子宮内死 亡率の増加は認められなかった。また、外表・内臟・骨格ともに催奇形性は認められなかった。

【まとめ】

酸化プロピレンは、1000 ppm の妊娠期のみの曝露では胚致死作用はみられなかったが、雌雄への 14 日間 の曝露後に受胎した場合には明らかな胚致死作用が認められた。ただし、1000 ppm の濃度は親動物への毒性 影響が強く、神経毒性や精巣毒性を示唆する所見もみられたことから、胚致死には親動物への毒性が関与し ていることが考えられた。

なお、これらの試験から得られた生殖及び発生の NOAELは、500 ppm と推察された。 本試験は厚生労働省の委託により実施した GLP 試験である。 